\title{
WHO AND WHAT SHOULD WE EDUCATE OUR STUDENTS TO BE? AN INQUIRY INTO THE CULTIVATION OF MULTICULTURALISM IN EDUCATION
}

\author{
LIPING WEI \\ pingping.wei@yahoo.com \\ University of Houston \\ USA
}

\begin{abstract}
A young Chinese immigrant's aversion to his Chinese origin and his self- identification as purely American gives much food for thought to the author: Who and what American education has been aiming to educate its students to be and what is impeding multiculturalism from being cultivated in education. The article points out that American schools have long been serving to Americanize its immigrant population regardless of where they are originally from, ethnically, linguistically, culturally, and religiously, and in spite of the country's long-standing and ever-growing diversity. Without challenging the structural inequality inherent in "assimilation", true multiculturalism will not be realized in education.
\end{abstract}

Key words: American education, immigrants, assimilation, multiculturalism.

“I'm American, not Chinese! Don't mistake me as Chinese! I'm fed up being thought by others to have anything to do with Chinese!"

Upon hearing these words, intuition may tell you that this is a person who has been wronged many times in terms of who he is, swollen with grievance and indignation, and nearly driven beyond the limit of his endurance! Nevertheless, are his words true? Let's pause and ask: Does he really have nothing to do with Chinese in any way?

Actually, he was born in China and immigrated to America with his parents at 8 years of age. Having received his school education all in America, in his late 20's now, the language he speaks has turned into English-only from Chinese-only. He becomes antipathetic towards associating with Chinese or being identified as Chinese, though he grew up in a Chinese immigrant family, was raised on Chinese cuisine, with all his relatives still in China, and all his parents' friends being Chinese. This is Allen, the only son of our friend Lao Zhang, who feels hurt, but more helpless ${ }^{1}$.

As a former educator and a current doctoral student of education who is an immigrant myself, I couldn't help but wonder: Why does an immigrant child enter the American educational system as an immigrant and exit as merely an American? Why can't an immigrant child grow up taking pride in where he originally comes from? Why can't he composedly proclaim "I'm American with my roots in blah blah blah?" Do immigrant children have to abandon their origin to better integrate into American culture and fit into society? What role has American education served and

\footnotetext{
All names are pseudonyms.
} 
is serving in cultivating in kids from various ethnic backgrounds the self-identification of who they are and what they are? Is American education aiming to uphold its diversity or dilute that diversity and "Americanize" everyone regardless of where they are originally from, ethnically, linguistically, culturally, and religiously? These are the questions that deserve the consideration of every educator.

\section{MULTICULTURALISM: A CALL FROM ASSIMILATION}

In a letter to the president of the American Defense Society in 1919, Theodore Roosevelt made the following statement: "There can be no divided allegiance here. Any man who says he is an American, but something also, isn't an American at all. We have room but for one flag, the American flag... We have room for but one language here, and that is the English language, for we intend to see that the crucible turns our people out as Americans, and American nationality, and not as dwellers in a polyglot boarding house; and we have room for but one soul loyalty, and that is loyalty to the American people" (Roosevelt 1919).

What turns out as reality doesn't disappoint T. Roosevelt: American education has been doing well at "Americanizing" its diverse population from generation to generation, which can even be traced back to the early times of New England when the earliest public, tax-supported school system took on the responsibility of transforming the children of European immigrants and Native Americans into American citizens (Frey, Whitehead 2009). Since then, public schools have become the primary institutions charged with assimilating the heterogeneous masses and creating a suitable workforce for a developing American nation (Tyack, Hansot 1982).

Assimilation, with a beautiful name "melting point", has remained the dominant strategy in American schools, with ruling white Protestant elite setting the curriculum, standards, and assessments for each succeeding generation, imprinting students with white middle class values (Ferguson 2001), and those students who resist this assimilation are doomed to go through psychological and emotional struggle and are frequently labeled "at-risk" leading to their marginalization and subsequent failure.

Fortunately, a growing body of educators are rising to challenge the ingrained "assimilation", appealing to public education for the fostering of multiculturalism within schools. However, despite an increasing voice questioning the validity of assimilation and advocating multiculturalism in education as never before, the effects in schools are far from transparent. An important reason is the false multiculturalism being implemented rather than a true multiculturalism.

\section{FALSE MULTICULTURALISM}

Many educators, while espousing the ideals of multiculturalism verbally, actually think and act in contradictory ways. The words most often heard with reference to "multiculturalism" may be "respect", "appreciation" and "tolerance", with the most commonly used strategy -exposing students to a wide range of customs, traditions and religions different from their own. It may help promote students' awareness of cultural differences, but with "White dominance" -the 
most fundamental ideal of "assimilation" - left to be touched upon and questioned, it does little to contribute to multiculturalism in a real sense, because the assumption underlying such an approach to multiculturalism is: Anglo Americans are representative of the norm, and others, though deviant from the norm, should be acknowledged too.

Rather than cultivate multiculturalism, this mentality actually cements the existing divisiveness and inequality. As Jennifer Banister and Michelle Maher pointed out, what should be called into question is not whether to celebrate non-Anglo Americans, but the notion always taken for granted: There is only one choice standard, entitled, and desired; it is the dominance of Whites, Christianity, hetereosexuality, English language, and loyalty to America (Banister, Maher 1998).

To perpetuate the existing system conferring power and privilege on Anglo Americans, students, regardless of who and what they originally are, are educated to take whatever is "filled" by teachers and completely internalize whatever image projected on them without questioning. Consequently, education in the interests of the "mainstream" only results in the "non-mainstream" adapting to the world as it is and identifying with the "mainstream". This is exactly how "Allen", and probably many other "Allens", have come into being. With few educators realizing and reacting to it, American education will continue to mold countless "Allens" who will be stamped with the same identification regardless of race, ethnicity, home language, culture, gender and sexual orientation, religion, and social class.

Therefore, without ceasing to remain blind or even denying to the taken-for-granted White norms, multiculturalism would go anywhere than a true democratic equalizer. However, how should educators implement a true multicultural education?

\section{WAYS TO MOVE TOWARDS TRUE MULTICULTURALISM}

Encourage students to challenge the concept of "assimilation". As a vital driving force of multiculturalism, educators should engage students in a critical investigation of the deep-seated system that features homogeneity rather than diversity, and Euro-centered values without equal acknowledgement of other contributions to human civilization. Unless young people are empowered to critically investigate "assimilation", question the false perceptions of "reality", quest for the truth, and fight for transformation upon critical reflection, they will not realize the structural inequality underpinning the ideals of "assimilation", and multiculturalism cannot be advanced radically.

Help immigrant students develop a positive self-identification. Schools are an important venue that informs students about their ability, shows how other people see them, and ultimately contributes to the development of their self-identification. Educators should help students see that people may come from different ethnic backgrounds, speak different languages as their mother tongue, hold different religious beliefs, form different gender and sexual identifications, and develop different ways of thinking and approaching the world, etc; however, no particular trait is superior or inferior to, or more or less entitled or desired than 
others. With diligence and talents, all can bring this nation a countributing force to make it a better place. Only on this basis can immigrant students develop a genuine appreciation of their origin from the bottom of their heart and a positive identification of who and what they are.

Teach multiculturally rather than multiculturalism. Multicultural education should be conducted as a critical perspective embedded throughout the curriculum rather than as a separate subject. This means teaching itself should be and can be multicultural, which is reflected in how each student is treated, how teaching content is presented, how dialogues are engaged, etc. Multiculturalism should be incorporated into the existing curriculum; no matter what content a teacher teaches, multicultural perspectives should always constitute a primary theme.

\section{CLOSING REMARKS}

In general, who and what we seek to educate our students to be are the informed citizens who take pride in the diversity they bring to this country, which makes the country unique. Educating immigrant children to be simply American without maintaining their original languages and cultures is not an indication of how successful American education is. Instead, it is a roadblock to the sustenance of the prosperity of the nation.

Education is a battleground of the larger war for civil rights and social justice. It is also the best hope for the fulfillment of all individuals, regardless of race, ethnicity, culture, social class, gender, ability, and language. In order for all "Allens" to be able to see who they are and what they are positively without sliding into extremes, it is incumbent upon our educators to construct "an empowering school culture" by "creating a learning environment in which students from diverse racial, ethnic, and social groups believe that they are heard and are valued and experience respect, belonging, and encouragement" (Parks 1999, p. 4). This is not a goal individual educators in isolation can attain. Only when the entire society, policymakers, community, parents, together with educators and students, all commit to this undertaking, can the change occur to cultivate true multiculturalism in education.

\section{BIBLIOGRAPHY}

Banister J., Maher M. (1998), Recentering multiculturalism: Moving toward community,

"Urban Education" 33(2).

Ferguson A.A. (2001), Bad boys: Public schools in the Making of Black Masculinity, University of Michigan Press, Michigan.

Frey C., Whitehead D. (2009), International education policies and the boundaries of global citizenship in the US, "Journal of Curriculum Studies" 41(2).

Parks S. (1999), Reducing the effects of racism in schools, "Educational Leadership" 56(6).

Tyack D., Hansot E. (1982), Managers of virtue, Basic Books, New York.

\section{NETOGRAPHY}

Roosevelt T. (1919), Letter to American Defense Society, 03.11.1919, http:/ / www.theodoreroosevelt.org/ tr\%20web\%20book/tr_cd_to_html280.html, retrieved: 15.11.2012. 